\title{
Interaction of Sulfur Dioxide with Aqueous Solutions of Amides
}

\author{
R. E. Khoma, M. I. Gavrilenko, and V. I. Nikitin ${ }^{\dagger}$ \\ Mechnikov National University, Odessa, Ukraine
}

Received June 19, 2003

\begin{abstract}
The interactions in the systems $\mathrm{H}_{2} \mathrm{O}-\mathrm{Am}-\mathrm{SO}_{2}$ (Am is formamide, dimethylformamide, acetamide, urea, tetramethylurea, tert-butylurea) at 278 and $293 \mathrm{~K}$ were studied pH-metrically. The results suggest formation of intermolecular and ion-molecule associates. The composition and stability of the compounds formed strongly depend on the structure and concentration of the solution components and on temperature.
\end{abstract}

The possible reactions of $\mathrm{SO}_{2}$ with compounds of various classes are very diverse, and studies of the behavior of $\mathrm{SO}_{2}$ in aqueous solutions are of not only theoretical but also practical importance [1].

It is known that sulfur dioxide forms a hydrate ("sulfurous acid") in aqueous solutions. However, actually, according to the experimental data, this is an associate $\mathrm{H}_{2} \mathrm{O} \cdot \mathrm{SO}_{2}$ rather than a covalent compound $\mathrm{H}_{2} \mathrm{SO}_{3}$. According to [2], sulfur dioxide hydrate undergoes further transformations:

$$
\begin{gathered}
\mathrm{H}_{2} \mathrm{O} \cdot \mathrm{SO}_{2} \stackrel{K_{1}}{\rightleftarrows} \mathrm{HSO}_{3}^{-}, \\
2 \mathrm{HSO}_{3}^{-} \stackrel{K^{*}}{\rightleftarrows} \mathrm{S}_{2} \mathrm{O}_{5}^{2-}+\mathrm{H}_{2} \mathrm{O}, \\
\mathrm{HSO}_{3}^{-} \stackrel{K_{2}}{\rightleftarrows} \mathrm{H}^{+}+\mathrm{SO}_{3}^{2-} .
\end{gathered}
$$

Sulfur dioxide reacts with amines in water to form ionic and covalent adducts [3]. Sulfite compounds react with carbonyl derivatives. The reactions of sulfurous compounds with ketones and aldehydes in aqueous solutions were studied in $[4,5]$.

Amides as Lewis bases occupy a particular place in coordination chemistry. Their molecules have two electron-donor centers: carbonyl oxygen and amine nitrogen atoms. The available experimental and theoretical data indicate that both protonation of amides and their coordination with metal ions mainly occur via $\mathrm{O}$ atom [6-8]. However, according to the NMR and UV data, the proton in dilute aqueous solutions of acids can also add to the nitrogen atom of amides $[9,10]$. The coordination mode depends on various factors [11].

It should be noted that the interaction of amides

\footnotetext{
$\dagger$ Deceased.
}

with $\mathrm{SO}_{2}$ was studied only in a few papers. Our previous potentiometric study of the interaction of $\mathrm{SO}_{2}$ with aqueous $(0.1,0.25$, and $0.5 \mathrm{M})$ solutions of urea in the temperature range $273-313 \mathrm{~K}$ [12-15] revealed formation of the compounds $h \mathrm{H}_{2} \mathrm{O} \cdot m \mathrm{CO}\left(\mathrm{NH}_{2}\right)_{2}$. $n \mathrm{SO}_{2}$ with the molar ratios $m: n=4: 1,2: 1,3: 2$, $1: 1,4: 5$, and $1: 2$. According to [12], the temperature affects not only the stability of $\mathrm{SO}_{2}$-urea associates in water but also the nature of bonding in the associates. Okhotnikova et al. [16] studied the system $\mathrm{H}_{2} \mathrm{O}-\mathrm{CO}\left(\mathrm{NH}_{2}\right)_{2}-\mathrm{SO}_{2}$ conductometrically in the range $298-353 \mathrm{~K}$. Data on interactions of $\mathrm{SO}_{2}$ with other amides are lacking.

The goal of this study was to analyze potentiometrically the interaction of $\mathrm{SO}_{2}$ with aqueous solutions of amides and to determine the component composition of these systems.

To this end, we studied absorption of $\mathrm{SO}_{2}$ with aqueous solutions of formamide, dimethylformamide, acetamide, tetramethylurea, and tert-butylurea and compared the results with the available data on the interaction of $\mathrm{SO}_{2}$ with aqueous urea solutions at 278 and $293 \mathrm{~K}$.

From the results of potentiometric studies of the interaction of aqueous amide solutions with $\mathrm{SO}_{2}$, we plotted the integral (Fig. 1) and differential (Fig. 2) titration curves. The integral $\mathrm{pH}$-metric curves contained several plateaus (Fig. 1), and the differential curves, more than two extrema (Fig. 2), suggesting formation of different compounds by amides and $\mathrm{SO}_{2}$ in water (Table 1). In most cases, the extrema in the differential curves are observed at $Q_{\mathrm{Am}}: Q_{\mathrm{SO}_{2}}=2: 1$ and 1:1 $\left(Q_{\mathrm{Am}}\right.$ is the total content of the amide in solution, equal to $0.1 \mathrm{M}$ ). This fact suggests formation of the compounds $2 \mathrm{Am} \cdot \mathrm{SO}_{2} \cdot n \mathrm{H}_{2} \mathrm{O}(\mathbf{I})$ and $\mathrm{Am} \cdot \mathrm{SO}_{2}$. $m \mathrm{H}_{2} \mathrm{O}$ (II) (where Am is formamide, dimethylformamide, acetamide, urea, tetramethylurea, tert-butyl- 


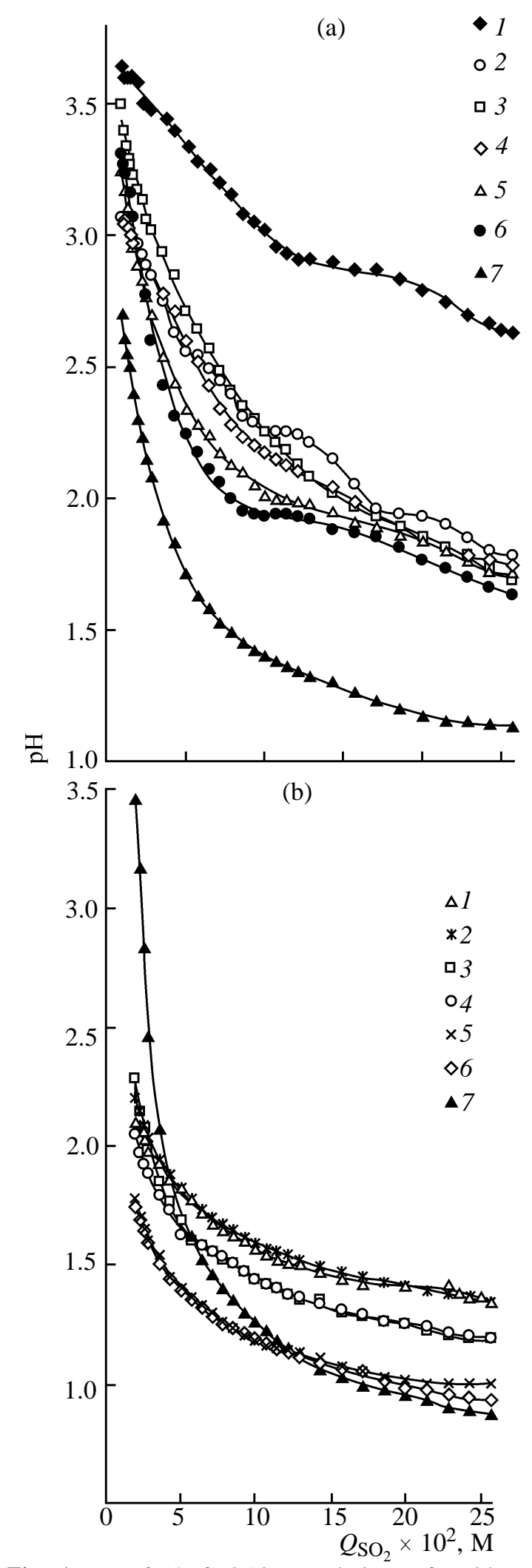

Fig. 1. $\mathrm{pH}$ of $(1-6) 0.10 \mathrm{M}$ solutions of amides and (7) water as a function of the amount of $\mathrm{SO}_{2}$ taken up $\left(Q_{\mathrm{SO}_{2}}, \mathrm{M}\right)$ at (a) 278 and (b) $293 \mathrm{~K}$. Amide: (1) urea [12], (2) tetramethylurea, (3) formamide, (4) acetamide, (5) tert-butylurea, and (6) dimethylformamide.

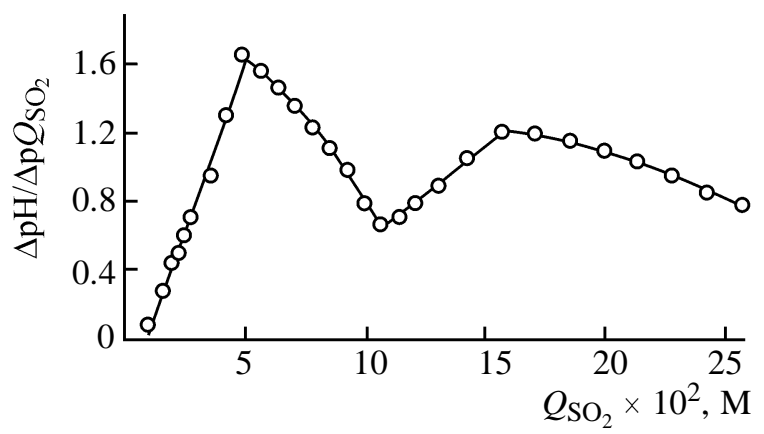

Fig. 2. Differential curve of titration of a $0.10 \mathrm{M}$ acetamide solution with gaseous $\mathrm{SO}_{2}$ at $278 \mathrm{~K}$.

urea) at $278 \mathrm{~K}$ (other ratios were not taken into account further).

Since the $\mathrm{pH}$ values at $278 \mathrm{~K}$ of aqueous solutions containing $\mathrm{SO}_{2}$ and amides are higher than those of the amide-free solutions with the same $\mathrm{SO}_{2}$ content (Fig. 1a), the following reactions can be assumed in these systems:

$$
\begin{gathered}
2 \mathrm{Am}+\mathrm{H}_{2} \mathrm{O} \cdot \mathrm{SO}_{2}+(n-1) \mathrm{H}_{2} \mathrm{O} \stackrel{\beta_{\mathrm{I}}}{\rightleftarrows} 2 \mathrm{Am} \cdot \mathrm{SO}_{2} \cdot n \mathrm{H}_{2} \mathrm{O} \\
\mathrm{Am}+\mathrm{H}_{2} \mathrm{O} \cdot \mathrm{SO}_{2}+(m-1) \mathrm{H}_{2} \mathrm{O} \stackrel{\mathrm{B}_{\mathrm{II}}}{\rightleftarrows} \mathrm{Am} \cdot \mathrm{SO}_{2} \cdot m \mathrm{H}_{2} \mathrm{O} \\
\mathrm{Am}+\mathrm{H}^{+} \rightleftarrows \mathrm{AmH}^{+}
\end{gathered}
$$

Also, dissociation of I and II into counterions (uronium cations and hydrosulfite and pyrosulfite anions) is possible.

As for the interaction of $\mathrm{SO}_{2}$ with aqueous solutions of amides at $293 \mathrm{~K}$, here we could expect a similar course of the pH-metric titration curves. Indeed, in the differential curves we observed extrema at $Q_{\mathrm{Am}}: Q_{\mathrm{SO}_{2}}=2: 1$ and $1: 1$ (Table 1). However, at $293 \mathrm{~K}$ the $\mathrm{pH}$ values of aqueous solutions containing amides and $\mathrm{SO}_{2}$ are lower compared to the amide-free solutions with the same $\mathrm{SO}_{2}$ content (Fig. 1b). Such a relationship is characteristic of all the systems studied at $Q_{\mathrm{SO}_{2}} \leq 0.05 \mathrm{M}$ and of solutions of acetamide and tert-butylurea at $Q_{\mathrm{SO}_{2}} \leq 0.1 \mathrm{M}$.

We believe that such a change in the $\mathrm{pH}$ is caused by the shift of the equilibrium of reaction (1) to the right on adding amides to aqueous solutions of $\mathrm{SO}_{2}$. This shift, in turn, is due to easier association of the amide molecules with hydrosulfite or pyrosulfite ions than with the neutral $\mathrm{SO}_{2}$ molecules. This results in predominant formation of anionic ion-molecule associates $2 \mathrm{Am} \cdot \mathrm{HSO}_{3}^{-}(\mathbf{I I I})$ or $4 \mathrm{Am} \cdot \mathrm{S}_{2} \mathrm{O}_{5}^{2-}(\mathbf{I V})(\mathrm{Am}=$ formamide, dimethylformamide, acetamide, urea, tetramethylurea, tert-butylurea), and $\mathrm{Am} \cdot \mathrm{HSO}_{3}^{-}(\mathbf{V})$ or 
Table 1. Composition of compounds in the systems $\mathrm{H}_{2} \mathrm{O}-\mathrm{Am}-\mathrm{SO}_{2}$

\begin{tabular}{l|c|c}
\hline \multirow{2}{*}{\multicolumn{1}{c}{ Amide }} & \multicolumn{2}{|c}{ Composition of complex, $Q_{\mathrm{Am}}: Q_{\mathrm{SO}_{2}}$} \\
\cline { 2 - 3 } & \multicolumn{1}{|c}{$278 \mathrm{~K}$} & \multicolumn{1}{|c}{$293 \mathrm{~K}$} \\
\hline Formamide & $2: 1,1: 1,4: 5,2: 3,1: 2$ & $2: 1,8: 5,8: 7,1: 1,2: 3,1: 2$ \\
Dimethylformamide & $4: 1,2: 1,4: 3,1: 1,2: 3,4: 7,1: 2$ & $2: 1,1: 1,2: 3,1: 2,4: 9$ \\
Acetamide & $2: 1,1: 1,2: 3$ & $4: 1,2: 1,4: 3,1: 1,4: 5,4: 7,1: 2$ \\
Urea & $2: 1,4: 3,1: 1,4: 5,2: 3,1: 2$ & $2: 1,4: 3,8: 7,1: 1,4: 5,2: 3,1: 2$ \\
Tetramethylurea & $4: 1,2: 1,1: 1,4: 5,2: 3,1: 2$ & $2: 1,4: 3,1: 1,4: 5,2: 3,1: 2$ \\
tert-Butylurea & $2: 1,1: 1,2: 3,1: 2$ & $2: 1,3: 2,1: 1,7: 8,1: 2$ \\
\hline
\end{tabular}

Table 2. Values of parameters in Eq. (16)

\begin{tabular}{c|c|c|c|c|c|c|c|c}
\hline$T, \mathrm{~K}$ & $Q_{\mathrm{SO}_{2}}, \mathrm{M}$ & Constant & $A_{0}$ & $-A_{1}$ & $A_{2}$ & $-A_{3}$ & $R$ & $n$ \\
\hline \multirow{2}{*}{278} & $0.01-0.20$ & $K_{1}$ & 3.86 & 35.46 & 311.24 & 829.28 & 0.990 & 28 \\
& & $K^{*}$ & -2.25 & 25.74 & 191.87 & 440.69 & 0.985 & 28 \\
293 & $0.02-0.20$ & $K_{1}$ & 4.86 & 62.71 & 465.57 & 1104.3 & 0.975 & 20 \\
& & $K^{*}$ & -2.40 & 7.49 & 13.06 & 0 & 0.975 & 20 \\
\hline
\end{tabular}

$2 \mathrm{Am} \cdot \mathrm{S}_{2} \mathrm{O}_{5}^{2-}(\mathbf{V I})(\mathrm{Am}=$ acetamide, tert-butylurea $)$. In the systems with formamide, dimethylformamide, urea, and tetramethylurea $\left(0.05<Q_{\mathrm{SO}_{2}} \leq 0.1 \mathrm{M}\right.$, $293 \mathrm{~K})$, the major species are compounds of type II:

$$
\begin{gathered}
2 \mathrm{Am}+\mathrm{HSO}_{3}^{-} \stackrel{\beta_{\text {III }}}{\rightleftarrows} 2 \mathrm{Am} \cdot \mathrm{HSO}_{3}^{-}, \\
4 \mathrm{Am}+\mathrm{S}_{2} \mathrm{O}_{5}^{2-} \stackrel{\beta_{\mathrm{II}}}{\rightleftarrows} 4 \mathrm{Am} \cdot \mathrm{S}_{2} \mathrm{O}_{5}^{2-} . \\
\mathrm{Am}+\mathrm{HSO}_{3}^{-} \stackrel{\beta_{\mathrm{v}}}{\rightleftarrows} \mathrm{Am} \cdot \mathrm{HSO}_{3}^{-}, \\
2 \mathrm{Am}+\mathrm{S}_{2} \mathrm{O}_{5}^{2-} \stackrel{\beta_{\mathrm{V}}}{\rightleftarrows} 2 \mathrm{Am} \cdot \mathrm{S}_{2} \mathrm{O}_{5}^{2-} .
\end{gathered}
$$

It should be noted that, at $293 \mathrm{~K}$, the $\mathrm{pH}$ values of aqueous formamide solutions virtually coincide with those of dimethylformamide solutions at $Q_{\mathrm{SO}_{2}}>$ $0.05 \mathrm{M}$; the same is true for the urea and tetramethylurea solutions. This fact indicates that the replacement of the hydrogen atoms of the amino groups in urea and formamide by the methyl groups does not affect the nature of interactions in formation of associates of type II at $293 \mathrm{~K}$.

It is known [17] that amides, especially formamide, can undergo acid-catalyzed hydrolysis with the formation of ammonium compounds. However, in all the cases the qualitative reactions for ammonium ions gave negative results.

After the supply of $\mathrm{SO}_{2}$ was stopped, the $\mathrm{pH}$ values of the reaction systems did not change during the period of $2 \mathrm{~h}$ and more. This fact indicates the establishment of an equilibrium in the systems. Thus, reactions (1)-(10) can be considered as equilibrium.

To determine the relative concentrations of sulfur compounds in an aqueous $\mathrm{SO}_{2}$ solution, it is first necessary to determine $K_{1}$ and $K^{*}$, since equilibrium (3) at $\mathrm{pH}<4.5$ can be neglected.

We constructed a system of equations reflecting the law of mass action [Eqs. (11), (12)] and the conditions of material balance [Eq. (13)] and electroneutrality [Eq. (14)].

$$
\begin{gathered}
K_{1}=\left[\mathrm{H}^{+}\right]\left[\mathrm{HSO}_{3}^{-}\right] /\left[\mathrm{H}_{2} \mathrm{O} \cdot \mathrm{SO}_{2}\right], \\
K^{*}=\left[\mathrm{S}_{2} \mathrm{O}_{5}^{2-}\right] /\left[\mathrm{HSO}_{3}^{-}\right]^{2}, \\
Q_{\mathrm{SO}_{2}}=\left[\mathrm{H}_{2} \mathrm{O} \cdot \mathrm{SO}_{2}\right]+2\left[\mathrm{~S}_{2} \mathrm{O}_{5}^{2-}\right]+\left[\mathrm{HSO}_{3}^{-}\right], \\
{\left[\mathrm{H}^{+}\right]=2\left[\mathrm{~S}_{2} \mathrm{O}_{5}^{2-}\right]+\left[\mathrm{HSO}_{3}^{-}\right] .}
\end{gathered}
$$

The concentration constants $K_{1}$ and $K^{*}$ were calculated by solving the system of Eqs. (11)-(14) using the pseudo-gradient method (for details, see [18, 19]). According to our results, the concentration dependence of $\mathrm{p} K_{1}$ and $\mathrm{p} K^{*}$ can be described by Eq. (15) with the parameters given in Table 2.

$$
\mathrm{p} K_{i}=A_{0}+A_{1} Q_{\mathrm{SO}_{2}}+A_{2} Q_{\mathrm{SO}_{2}}^{2}+A_{3} Q_{\mathrm{SO}_{2}}^{3} .
$$

From these data, we constructed the diagrams of the component composition of aqueous solutions of $\mathrm{SO}_{2}$ at 278 and $293 \mathrm{~K}$ (Fig. 3). 


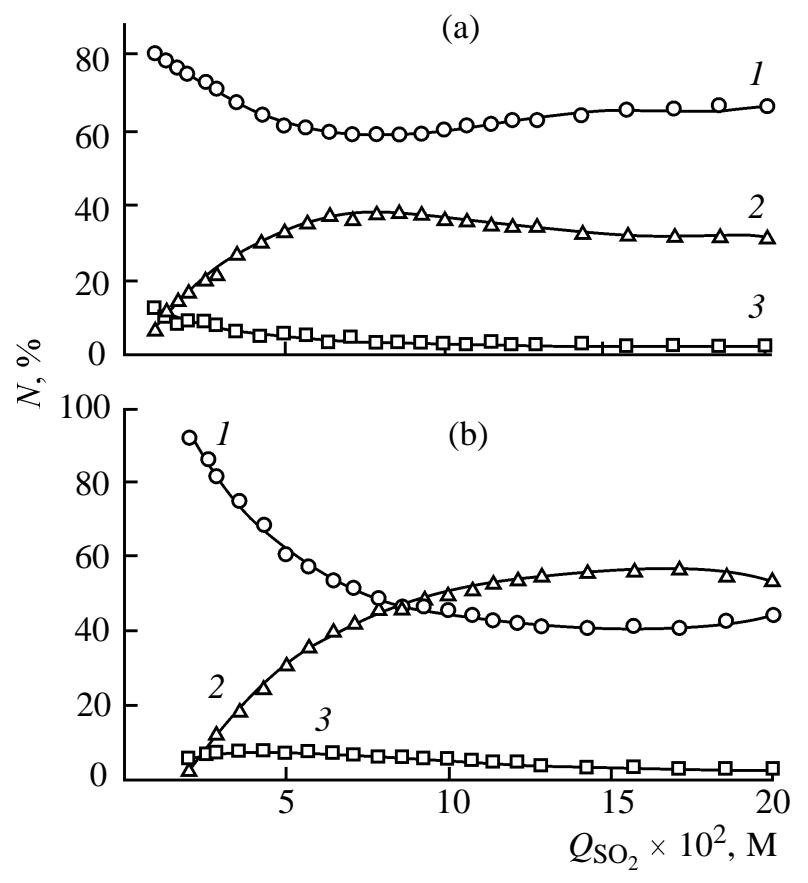

Fig. 3. Composition of aqueous $\mathrm{SO}_{2}$ solutions as a function of $Q_{\mathrm{SO}_{2}}$ at (a) 278 and (b) $293 \mathrm{~K}$. (N) Mole fraction of (1) $\mathrm{H}_{2} \mathrm{O} \cdot \mathrm{SO}_{2}$, (2) $\mathrm{HSO}_{3}^{-}$, and (3) $\mathrm{S}_{2} \mathrm{O}_{5}^{2-}$ (relative to the total $\mathrm{SO}_{2}$ content in the system).

$$
\begin{aligned}
N_{\mathrm{H}_{2} \mathrm{O} \cdot \mathrm{SO}_{2}} & =\left[\mathrm{H}_{2} \mathrm{O} \cdot \mathrm{SO}_{2}\right] / Q_{\mathrm{SO}_{2}}, \\
N_{\mathrm{HSO}_{3}^{-}} & =\left[\mathrm{HSO}_{3}\right] / Q_{\mathrm{SO}_{2}}, \\
N_{\mathrm{S}_{2} \mathrm{O}_{5}^{2-}} & =2\left[\mathrm{~S}_{2} \mathrm{O}_{5}^{2-}\right] / Q_{\mathrm{SO}_{2}} .
\end{aligned}
$$

Figure 3a shows that the mole fraction of sulfur dioxide hydrate (curve 1 ) in the system $\mathrm{SO}_{2}-\mathrm{H}_{2} \mathrm{O}$ at $278 \mathrm{~K}$ first decreases from $\sim 80$ to $\sim 58 \%$, reaches a minimum at $Q_{\mathrm{SO}_{2}} 0.078 \mathrm{M}$, and then increases to $\sim 66 \%$ (at $Q_{\mathrm{SO}_{2}} 0.2 \mathrm{M}$ ). The mole fraction of pyrosulfite ions (curve 2) as a function of the total content of $\mathrm{SO}_{2}$ in the system, on the contrary, first increases from $\sim 7$ to $\sim 38 \%$, reaches a maximum at $Q_{\mathrm{SO}_{2}} 0.078 \mathrm{M}$, and then decreases to $\sim 32 \%$ (at $Q_{\mathrm{SO}_{2}} 0.2 \mathrm{M}$ ). The mole fraction of hydrosulfite ions (curve 3 ) decreases from $\sim 12$ to $\sim 2 \%$ with an increase in $Q_{\mathrm{SO}_{2}}$ in the examined range.

As seen from Fig. 3b, in the $\mathrm{SO}_{2}-\mathrm{H}_{2} \mathrm{O}$ system at $293 \mathrm{~K}, N_{\mathrm{HSO}_{3}^{-}}<N_{\mathrm{S}_{2} \mathrm{O}_{5}^{2-}}<N_{\mathrm{H}_{2} \mathrm{O} \cdot \mathrm{SO}_{2}}$ at $0.025 \leq Q_{\mathrm{SO}_{2}} \leq$ $0.085 \mathrm{M}$ and $N_{\mathrm{HSO}_{3}^{-}}<N_{\mathrm{H}_{2} \mathrm{O} \cdot \mathrm{SO}_{2}}<N_{\mathrm{S}_{2} \mathrm{O}_{5}^{2-}}$ at $0.085 \leq$ $Q_{\mathrm{SO}_{2}} \leq 0.2 \mathrm{M}$. The content of hydrosulfite ions is $2-7 \%$ in the entire concentration range studied. However, at $293 \mathrm{~K}$, the above method allows determination of the component composition of the equilibrium $\mathrm{SO}_{2}-\mathrm{H}_{2} \mathrm{O}$ mixture and of the concentration constants $K_{1}$ and $K^{*}$ only at $Q_{\mathrm{SO}_{2}} \geq 0.02 \mathrm{M}$. This is apparently due to the fact that, at $Q_{\mathrm{SO}_{2}}<0.02 \mathrm{M}$, the relative content of pyrosulfite ions is negligible.

Taking into account Eqs. (11), (12), (19), and (20) reflecting the law of mass action and Eqs. (21)-(23) reflecting the conditions of material balance and electroneutrality, we calculated the apparent association constants $\beta_{\mathrm{I}}$ at $278 \mathrm{~K}\left(0.01 \leq Q_{\mathrm{SO}_{2}} \leq 0.05 \mathrm{M}\right)$ :

$$
\begin{gathered}
\beta_{\mathbf{I}}=[\mathbf{I}] /\left([\mathrm{Am}]_{2}\left[\mathrm{H}_{2} \mathrm{O} \cdot \mathrm{SO}_{2}\right]\right), \\
K_{\mathrm{a}}=[\mathrm{Am}]\left[\mathrm{H}^{+}\right] /\left[\{\mathrm{AmH}\}^{+}\right], \\
Q_{\mathrm{SO}_{2}}=\left[\mathrm{H}_{2} \mathrm{O} \cdot \mathrm{SO}_{2}\right]+2\left[\mathrm{~S}_{2} \mathrm{O}_{5}^{2-}\right]+\left[\mathrm{HSO}_{3}^{-}\right]+[\mathbf{I}], \\
Q_{\mathrm{Am}}=[\mathrm{Am}]+\left[\{\mathrm{AmH}\}^{+}\right]+2[\mathbf{I}], \\
{\left[\{\mathrm{AmH}\}^{+}\right]+\left[\mathrm{H}^{+}\right]=\left[\mathrm{HSO}_{3}^{-}\right]+2\left[\mathrm{~S}_{2} \mathrm{O}_{5}^{2-}\right]+\left[\mathrm{OH}^{-}\right],}
\end{gathered}
$$

where $Q_{\mathrm{Am}}$ is the total Am content in the system.

For the range $0.05<Q_{\mathrm{SO}_{2}} \leq 0.10 \mathrm{M}$ at $278 \mathrm{~K}$ (Fig. 1b), we took into account the simultaneous presence of I and II. To do this, we used a system of equations based on the law of mass action [Eqs. (11), (12), (19), (20), (24)] and the conditions of material balance [Eqs. (25), (26)] and electroneutrality [Eq. (23)]:

$$
\begin{gathered}
\beta_{\mathbf{I I}}=[\mathbf{I I}] /\left([\mathrm{Am}]\left[\mathrm{H}_{2} \mathrm{O} \cdot \mathrm{SO}_{2}\right]\right), \\
Q_{\mathrm{SO}_{2}}=\left[\mathrm{H}_{2} \mathrm{O} \cdot \mathrm{SO}_{2}\right]+2\left[\mathrm{~S}_{2} \mathrm{O}_{5}^{2-}\right]+\left[\mathrm{HSO}_{3}^{-}\right]+[\mathbf{I}]+[\mathbf{I I}], \\
Q_{\mathrm{Am}}=[\mathrm{Am}]+\left[\{\mathrm{AmH}\}^{+}\right]+2[\mathbf{I}]+[\mathbf{I I}] .
\end{gathered}
$$

As experimental determination of the concentrations of III and IV at $293 \mathrm{~K} 0.05<Q_{\mathrm{SO}_{2}} \leq 0.10 \mathrm{M}$ was impossible, it was difficult to determine $\beta_{\text {III }}$ and $\beta_{\text {IV. Therefore, we considered the apparent equilib- }}$ rium constants:

$$
\begin{aligned}
& \beta_{\mathbf{I I I}}=\frac{[\mathbf{I I I}]+2[\mathbf{I V}]}{[\mathrm{Am}]^{2}\left[\mathrm{HSO}_{3}^{-}\right]}, \\
& \beta_{\mathbf{I V}}=\frac{[\mathbf{I I I}]+2[\mathbf{I V}]}{[\mathrm{Am}]^{4}\left[\mathrm{~S}_{2} \mathrm{O}_{5}^{2-}\right]} .
\end{aligned}
$$

In this case, to calculate the equilibria, it is necessary to use a system of equations based on the law of mass action [Eqs. (11), (12), (20), (27), (28)] and the conditions of material balance and electroneutrality [Eqs. (29)-(31)].

$$
\begin{gathered}
Q_{\mathrm{SO}_{2}}=\left[\mathrm{H}_{2} \mathrm{O} \cdot \mathrm{SO}_{2}\right]+2\left[\mathrm{~S}_{2} \mathrm{O}_{5}^{2-}\right] \\
+\left[\mathrm{HSO}_{3}^{-}\right]+[\mathbf{I I I}]+1[\mathbf{I V}], \\
Q_{\mathrm{Am}}=[\mathrm{Am}]+\left[\{\mathrm{AmH}\}^{+}\right]+2[\mathbf{I I I}]+4[\mathbf{I V}], \\
{\left[\{\mathrm{AmH}\}^{+}\right]+\left[\mathrm{H}^{+}\right]=\left[\mathrm{HSO}_{3}^{-}\right]+2\left[\mathrm{~S}_{2} \mathrm{O}_{5}^{2-}\right]+\left[\mathrm{OH}^{-}\right]} \\
+[\mathbf{I I I}]+2[\mathbf{I V}] .
\end{gathered}
$$


Using similar reasonings, we calculated the equilibria for the range $0.05<Q_{\mathrm{SO}_{2}} \leq 0.10 \mathrm{M}$ at $293 \mathrm{~K}$.

In the calculations, we took $\mathrm{p} K_{\mathrm{a}}$ for formamide, dimethylformamide, acetamide, urea, and tetramethylurea equal to $-0.25,-0.70,0.10,0.50$, and 0.40 , respectively [20, 21]. The influence of temperature on the protonation of the amides was taken into account according to [22].

From these data, we constructed the diagrams of the component composition of the systems. The diagram for acetamide is shown as example in Fig. 4. In all the systems studied, the mole fraction of $\{\mathrm{AmH}\}^{+}$ does not exceed $0.1 \%$ of $Q_{\text {Am }}$, i.e., the protonation of amides [Eq. (7)] in these cases can be neglected. We found no published data on the protonation of tertbutylurea; in view of the above facts, the $\{\mathrm{AmH}\}^{+}$ concentration in aqueous solutions of tert-butylurea was assumed to be zero.

Comparison of Figs. 3 and 4 shows that the component composition of aqueous $\mathrm{SO}_{2}$ solutions largely depends on $Q_{\mathrm{SO}_{2}}$ and temperature, and also on the presence and structure of amides.

It should be noted that, in the vicinity of points in which the curves of $\mathrm{pH}$-metric titration of aqueous solutions with sulfur dioxide in the presence of an amide intercept with the curves taken in the absence of amides, it is impossible to determine the component composition of the systems (discontinuities of the second kind arise) and association constants (at $293 \mathrm{~K}$ ), because in this case (Fig. 4b) the differences between the $\mathrm{pH}$ values of the solutions in the presence and in the absence of amides, at the same $\mathrm{SO}_{2}$ content, are comparable with the experimental error [18].

From the experimental data, following the abovedescribed schemes, we calculated the apparent association constants $\beta_{\mathbf{I}}-\beta_{\mathbf{I V}}$. The concentration dependences of $\mathrm{p} \beta_{i}\left(-\log \beta_{i}\right)$ can be described by Eq. (32) with the parameters given in Tables 3 and 4 .

$$
\mathrm{p} \beta_{i}=A_{i}+B_{i} Q_{\mathrm{SO}_{2}}
$$

Tables 3 and 4 show that the $\mathrm{p} \beta_{i}$ values characterizing complexation processes (4), (5), and (7)-(10) are negative, suggesting spontaneous occurrence of these reactions.

According to the calculations, the dissociation of $\mathbf{I}$ and II into the counterions (as assumed above) is improbable, because the constants of these processes are less than unity (therefore, the equations of these reactions and their equilibrium constants are not given in this paper).
Table 3. Parameters of Eq. (32) for $278 \mathrm{~K}$

\begin{tabular}{|c|c|c|c|c|}
\hline $\mathrm{Am}$ & $-A_{i}$ & $-B_{i}$ & $R$ & $n$ \\
\hline$Q_{\mathrm{SO}_{2}}$ & $0.01-0.05$ & $\mathrm{M}, i=\mathbf{I}$ & & \\
\hline Formamide & 3.00 & 47.10 & 0.981 & 11 \\
\hline Dimethylformamide & 3.22 & 12.16 & 0.957 & 11 \\
\hline Acetamide & 2.05 & 64.90 & 0.998 & 11 \\
\hline Urea & 2.91 & 84.43 & 0.982 & 11 \\
\hline Tetramethylurea & 2.13 & 59.68 & 0.994 & 11 \\
\hline tert-Butylurea & 2.64 & 31.31 & 0.983 & 11 \\
\hline$Q_{\mathrm{SO}_{2}}$ & $0.01-0.05$ & $\mathrm{M}, i=\mathbf{I}$ & & \\
\hline Formamide & 2.07 & 19.73 & 0.980 & 8 \\
\hline Dimethylformamide & 1.19 & 16.92 & 0.987 & 8 \\
\hline Acetamide & 1.85 & 18.93 & 0.989 & 8 \\
\hline Urea & 2.84 & 33.52 & 0.971 & 12 \\
\hline Tetramethylurea & 1.69 & 21.70 & 0.977 & 8 \\
\hline tert-Butylurea & 1.28 & 19.57 & 0.980 & 8 \\
\hline
\end{tabular}

It should be noted that our model for calculating equilibria in the systems $\mathrm{H}_{2} \mathrm{O}-\mathrm{Am}-\mathrm{SO}_{2}$ (in contrast to the model suggested in [11]), in parallel with the possible association, takes into account the first step of dissociation of sulfurous acid and the dimerization

(a)
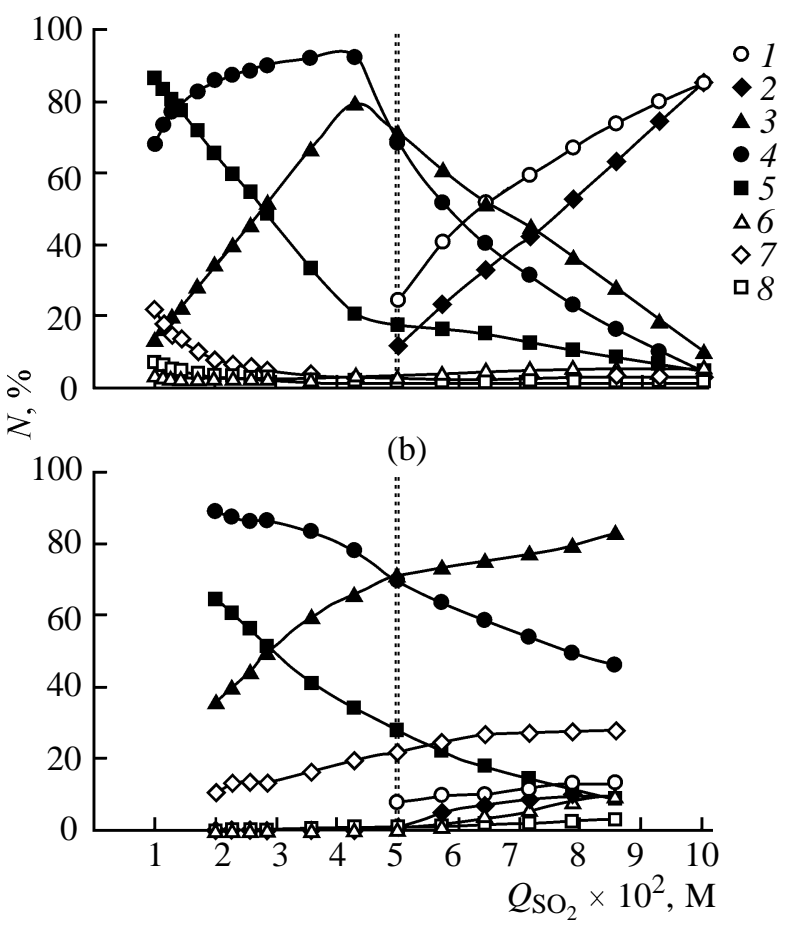

Fig. 4. Distribution of chemical species in the system $\mathrm{CH}_{3} \mathrm{CONH}_{2}-\mathrm{SO}_{2}-\mathrm{H}_{2} \mathrm{O}$ as influenced by $Q_{\mathrm{SO}_{2}}$ at (l) 278 and (b) $293 \mathrm{~K}$. $(N)$ Mole fraction of species relative to the total content of $(1-4,6-8) \mathrm{S}$ and $(2,3,5) \mathrm{N}$. Species: $(1,2)$ II, (3, 4) (a) I and (b) III, (5) $\mathrm{CH}_{3} \mathrm{CONH}_{2}$, (6) $\mathrm{S}_{2} \mathrm{O}_{5}^{2-}$, (7) $\mathrm{H}_{2} \mathrm{O} \cdot \mathrm{SO}_{2}$, and (8) $\mathrm{HSO}_{3}^{-}$. 
Table 4. Parameters of Eq. (32) for $293 \mathrm{~K}$

\begin{tabular}{|c|c|c|c|c|c|}
\hline$\underset{i}{\text { Complex }}$ & Am & $-A_{i}$ & $-B_{i}$ & $R$ & $n$ \\
\hline \multicolumn{6}{|c|}{$Q_{\mathrm{SO}_{2}} 0.02-0.05 \mathrm{M}$} \\
\hline III & Formamide & 4.33 & 33.54 & 0.974 & 7 \\
\hline III & Dimethylformamide & 4.26 & 21.46 & 0.974 & 7 \\
\hline III & Acetamide & 5.57 & 12.63 & 0.964 & 7 \\
\hline III & Urea & 4.40 & 44.68 & 0.985 & 9 \\
\hline III & Tetramethylurea & 4.20 & 34.61 & 0.972 & 7 \\
\hline III & tert-Butylurea & 5.59 & 12.59 & 0.984 & 7 \\
\hline IV & Formamide & 8.71 & 94.68 & 0.992 & 7 \\
\hline IV & Dimethylformamide & 8.02 & 58.47 & 0.990 & 7 \\
\hline IV & Acetamide & 10.39 & 43.85 & 0.982 & 7 \\
\hline IV & Urea & 8.42 & 102.44 & 0.997 & 9 \\
\hline IV & Tetramethylurea & 7.85 & 91.21 & 0.997 & 7 \\
\hline IV & tert-Butylurea & 10.36 & 43.71 & 0.994 & 7 \\
\hline \multicolumn{6}{|c|}{$Q_{\mathrm{SO}_{2}} 0.05-0.10 \mathrm{M}$} \\
\hline II & Formamide & 1.15 & -15.70 & 0.982 & 8 \\
\hline II & Dimethylformamide & 1.89 & -10.26 & 0.991 & 8 \\
\hline II & Urea & 1.29 & -15.21 & 0.996 & 8 \\
\hline II & Tetramethylurea & 1.27 & -15.69 & 0.984 & 8 \\
\hline \multicolumn{6}{|c|}{$Q_{\mathrm{SO}_{2}} 0.05-0.08 \mathrm{M}$} \\
\hline $\mathbf{V}$ & Acetamide & 3.58 & 14.83 & 0.983 & 6 \\
\hline $\mathbf{V}$ & tert-Butylurea & 3.56 & 14.85 & 0.994 & 6 \\
\hline VI & Acetamide & 6.45 & 34.68 & 0.985 & 6 \\
\hline VI & tert-Butylurea & 6.48 & 34.70 & 0.999 & 6 \\
\hline
\end{tabular}

of hydrosulfite ions into pyrosulfite ions [Eqs. (1) and (2)].

The lack of correlation between the stability of these compounds and the basicity of the amides suggests that interaction of $\mathrm{SO}_{2}$ with aqueous solutions of amides results in formation of different types of associates at the same composition [18], i.e., the coordination modes are different. The above-described effects are most probably due to selective solvation in aqueous-amide solutions of $\mathrm{SO}_{2}$ [23].

Thus, the interactions in water-amide- $\mathrm{SO}_{2}$ systems and the component composition of these systems largely depend on the structure and concentration of the components and on temperature. When calculating equilibria in these systems, it is necessary to take into account both the first step of sulfurous acid dissociation and the dimerization of hydrosulfite ions into pyrosulfite ions. The protonation of amides in these systems can be neglected.

\section{EXPERIMENTAL}

As starting reagents we used analytically pure grade formamide, dimethylformamide, acetamide, and tetramethylurea; tert-butylurea was prepared according to [24]. The experimental procedure is described in detail in [12-14]. The experiments were performed at 278 and $293 \mathrm{~K}$.

Ammonium ions were determined qualitatively with Nessler's reagent.

In the course of experiments, the $\mathrm{SO}_{2}$ concentration was monitored iodometrically at the outlet from the reaction mixture at 15-20-s intervals [25]. The amount of converted $\mathrm{SO}_{2}$ was determined experimentally by Schoeniger's method [26] and calculated as follows:

$$
Q_{\mathrm{SO}_{2}}=\frac{q\left(\left[\mathrm{SO}_{2}\right]_{\text {in }}-\left[\mathrm{SO}_{2}\right]_{\mathrm{f}}\right)}{V_{1}}, \mathrm{M},
$$

where $V_{1}$ is the solution volume, $1 ;\left[\mathrm{SO}_{2}\right]_{\text {in }}$ and $\left[\mathrm{SO}_{2}\right]_{\mathrm{f}}$, $\mathrm{SO}_{2}$ concentration in the gas mixture before and after the reaction, respectively, $\mathrm{M} ; q$, gas mixture volume, 1 , passed through the reactor in time $\tau$.

Three replicate experiments were performed in each case. The random error of the experiment at $Q_{\mathrm{SO}_{2}} \geq 0.01 \mathrm{M}$ did not exceed $2.5 \%$ in all the cases.

\section{REFERENCES}

1. Vilesov, N.G. and Bol'shunov, V.G., Utilizatsiya promyshlennykh sernistykh gazov (Utilization of Industrial Sulfur-Containing Gases), Kiev: Naukova Dumka, 1990.

2. Pereda, S., Thomsen, K., and Rasmussen, P., Chem. Eng. Sci., 2000, vol. 55, no. 14, p. 2663.

3. Kurando, S.V., Cand. Sci. (Chem.) Dissertation, Odessa, 1995.

4. Orsnes, H., Grat, T., and Degn, H., Anal. Chem., 1998, vol. 70, no. 22, p. 4751.

5. Olson, T.M., Torry, L.A., and Hoffmann, M.R., Environ. Sci. Technol., 1988, vol. 22, no. 11, p. 1284.

6. Gel'mbol'dt, V.O., Koroeva, L.V., and Ganin, E.V., Koord. Khim., 2000, vol. 26, no. 1, p. 15.

7. Kuz'mina, N.E., Palkina, K.K., Savinkina, E.V., Kozlova, I.A., and Kuznetsov, N.T., Zh. Neorg. Khim., 2000, vol. 45, no. 1, p. 10.

8. Valentine, B., Amour, T.E.St., and Fiat, D., Org. Magn. Reson., 1984, vol. 22, no. 11, p. 697.

9. Liler, M. and Morris, D.G., J. Chem. Soc., Chem. Commun., 1975, no. 3, p. 93.

10. Benderly, H. and Rosencheck, K., J. Chem. Soc., Chem. Commun., 1972, no. 3, p. 179.

11. Ostrovskii, V.A. and Koldobskii, G.I., Slabye organicheskie osnovaniya (Weak Organic Bases), Leningrad: Leningr. Gos. Univ., 1990, p. 95.

12. Khoma, R.E., Nikitin, V.I., and Gavrilenko, M.I., Izv. 
Vyssh. Uchebn. Zaved., Khim. Khim. Tekhnol., 2001, vol. 44, no. 6, p. 42.

13. Nikitin, V.I., Khoma, R.E., and Gavrilenko, M.I., Izv. Vyssh. Uchebn. Zaved., Khim. Khim. Tekhnol., 2000, vol. 43, no. 2, p. 14.

14. Gavrilenko, M.I., Nikitin, V.I., and Khoma, R.E., Sbornik nauchnykh trudov Mezhdunarodnoi nauchnotekhnicheskoi konferentsii "Sovremennye problemy khimicheskoi tekhnologii neorganicheskikh veshchestv" (Coll. of Scientific Papers of Int. Scientific and Technical Conf. "Modern Problems of Chemical Technology of Inorganic Substances"), Odessa, 2001, vol. 1, p. 38 .

15. Khoma, R.E., Nikitin, V.I., and Gavrilenko, M.I., Zh. Prikl. Khim., 2003, vol. 76, no. 4, p. 533.

16. Okhotnikova, O.P., Kostoglod, O.B., Astrelin, I.M., and Knyazev, Yu.V., Sbornik nauchnykh trudov Mezhdunarodnoi nauchno-tekhnicheskoi konferentsii "Sovremennye problemy khimicheskoi tekhnologii neorganicheskikh veshchestv" (Coll. of Scientific Papers of Int. Scientific and Technical Conf. "Modern Problems of Chemical Technology of Inorganic Substances"), Odessa, 2001, vol. 2, p. 156.

17. Nurakhmetov, N.N. and Beremzhanov, B.A., Zh. Neorg. Khim., 1978, vol. 23, no. 2, p. 504.

18. Beck, M.T. and Nagypal, I., Chemistry of Complex Equilibria, Budapest: Akad. Kiado, 1985.
19. Romanenko, S.A., Cand. Sci. (Chem.) Dissertartion, Leningrad, 1986.

20. Adelman, R.L., J. Org. Chem., 1964, vol. 29, no. 7, p. 1837.

21. Wada, G. and Takenaka, T., Bull. Chem. Soc. Jpn., 1971, vol. 44, no. 10, p. 2877.

22. Albert, A. and Serjeant, E., Ionization Constants of Acids and Bases. A Laboratory Manual, New York: Wiley, 1962.

23. Khurgin, Yu.I., Kudryashova, V.A., and Zavizion, V.A., Izv. Akad. Nauk SSSR, Ser. Khim., 1990, no. 2 , p. 321.

24. Organic Syntheses, Blatt, A.H., Ed., New York: Wiley, 1944. Translated under the title Sintezy organicheskikh preparatov, Moscow: Inostrannaya Literatura, 1954, coll. 4.

25. Kel'man, I.N., Brutskus, E.B., and Osherovich, R.Kh., Metody analiza pri kontrole proizvodstva sernoi kisloty i fosfornykh udobrenii (Analytical Methods in Monitoring of Production of Sulfuric Acid and Phosphorus Fertilizers), Moscow: Khimiya, 1965, pp. 200-204.

26. Klimova, V.A., Osnovnye metody analiza organicheskikh soedinenii (Main Methods for Organic Analysis), Moscow: Khimiya, 1975. 